\title{
POSSIBLE USE OF HEMP AND WOOD IN PRODUCTION OF THE HEAT INSULATION MATERIALS
}

\author{
Martins Andzs, Voldemars Skrupskis \\ Latvian University of Agriculture, Forest Faculty \\ Latvia, Jelgava, Dobeles Street 41, Department of Woodworking \\ Phone: +(371) 29397439, +(371) 63083317; \\ e-mail: martins.andzs@gmail.com,koka@llu.lv
}

\begin{abstract}
Obtaining of a new ecological heat insulation material from always renewable raw material in nature, wood and hemp, derived from wood and hemp fibre remains left from the production process. The study was carried out to find hemp wood parts (shives), fiber, and material first possible compositions together with wood fibres, to produce heat insulation materials. The use of the heat insulation material would be meant for dwelling and recreation houses. In the present research the main characteristics of these materials are determined: moisture content, density, water absorption, as well as the coefficient of heat transmission.
\end{abstract}

Keywords: hemp, hemp heat insulation, wood-fibre heat insulation.

\section{Introduction}

Already from the ancient times the world has known natural materials such as wood, hemp, clay, stone and other materials that easily return to natural circulation after their usage and require the least energy in manufacture and processing.

One of the fundamental principles of the economical, social and environmental policy of the Republic of Latvia is the maximal usage of the advantages of geographical location by promoting the development of industries with access to the local raw materials. The forest sector and agriculture is one of the few sectors in which it is possible to achieve economical mobility and increase production on the basis of the renewable raw materials, ensuring economical stability of the environment in the country.

Though the forest and agricultural areas can not be measured solely in monetary terms; they perform essential environmental, ecological and social functions at both national and international level [1]. Due to the development of agriculture in Latvia and the interest about the acquisition of new market niches there were experimentally planted hemp plantations in Kraslava.

Initial aim of the production was to produce fibres, but due to the fact that it is possible to obtain from the hemp 23-27\% fibres, but more than 65\% - shafts, there occurred a problem with the large amount of shive.

Since in the wood-working process there are many different wood wastes, it led to a conclusion to carry out a study about the possibility of joining both wastes as well as the possibility of the heat insulating material production, in which the first heat insulation composite material samples would be obtained.

In the world there are only few researches available about the joining of hemp and wood, resulting in heat insulation materials. The obtained results are often very controversial and ambiguous.

Due to the development of human thinking about a healthy environment, there is a need for new environmentally friendly materials. Hemp, hemp and wood materials for heat insulation in the world are still new products, being only in stage of development. That is why it is necessary to carry out researches about the creation of new materials and improvement of the existing ones, besides they should meet all the necessary standards and construction norms of Latvia and European Union (EU). This is the first study of this kind in Latvia. 


\section{Materials and methods}

The aim of the study is to create an insulation material from Latvian-grown hemp fibres and hemp wooden parts, as well as from wood fibres and pulp and to test the physical properties of the insulation materials. At the beginning stage of the research I select the necessary relation of binders and various fibres.

Physical properties which I am going to study will be: density, water absorption capacity temporarily standing in water, moisture content, and heat conductivity.

The first material, which was made of hemp fibre, is hemp-fibre insulation material (soft plate). Hemp fibre wood parts (shive) were obtained from the company "ZALERS" in Kraslava district, but the wood fibres - from the company "Yelt Wen" in Aizkraukle district. The process proceeded as follows.

Hemp is harvested from the field, ground in hammermill and the wooden part is separated from the fibre parts in the drum separator. Then to separate the fibres from the impurities (sand, small stones) they must be blown with an air flow. In the shive fraction there still remains an average of $4-12 \%$ fibres, so it requires another technological operation with the help of a sieve, where with the flow of air fibres are separated from the shives.

In the study I used two binders, NaSl Sodium silicate solution (water glass), as well as potato starch, since these materials are known with their moisture-repellent function and are created from natural ingredients. During the course of the process, soda as an agent against burning was added to the composition.

Binder was applied on both sides with a spray method. At first one side was covered with a binder, and then it was repeated on the other side. After that comes the cutting of insulation according to how long this soft insulation board will be. All samples including the insulation materials presented in the table were produced with an area of $300 \mathrm{~mm} * 300 \mathrm{~mm}$, but with different thicknesses depending on the necessity for each study.

The next operation is smoothing of the fibre by the rollers. This technological operation is required to smooth the fibres and to make equally thick technological isolation work pieces. Then these work pieces are formed according to how thick the insulating plate is foreseen. After that the finished plate is pressed and dried in oven at $150^{\circ} \mathrm{C}$, and by the end of the operation $-120^{\circ} \mathrm{C}$, as the fibre was already heated through previously.

In conclusion, plates are kept 24 hours in a room with constant air and temperature values to stabilize the moisture content.

Then the insulation material is kept in a conditioning chamber at $23 \pm 2{ }^{\circ} \mathrm{C}$ with a relative humidity of WR $50 \pm 5 \%$. In the study, due to the fact that in order to check the coefficient of heat transmission $\lambda \mathrm{W} /(\mathrm{m} * \mathrm{~K})$, the maximum sample thickness that can be inserted into the test facility, is $25 \mathrm{~mm}$. 10 samples of each type were produced.

The next samples were made by mixing wood fibres in different proportions with hemp shive parts mixed in different proportions, according to the principle of board production technology, by the dry method.

After the production of the samples, 4 types of samples were selected and further in text they will be marked as A1, B1, C1, D1, whose compositions can be seen in Table 1.

Product samples were examined visually and by the mechanical strength by breaking them with the hands, as a part of the samples after pressing did not have sufficient stiffness. The material, for that potato starch was used as a binder, had the greatest mechanical strength.

The study was carried out in accordance with the Latvian National Standards: Thermal insulating materials for the usage. Determination of the apparent density LVS EN 1602:1996 + AC: 1997. [2].

Thermal insulation products for building. Water absorption determination temporarily and partly standing in water. BS EN 1609:1996 + AC: 1997. [3]. Thermal insulation. Thermal 
resistance and determination of the related properties in steady condition. Enclosed hot plate device, LVS ISO 8302:1991 [4].

For the determination of the thermal conductivity Laboratory for Mathematical Modelling of Environmental and Technological processes was used. The data were processed with program Isis v.1.0.1.

\section{Results and Discussion}

Experimental data confirm that it is possible to get insulating composite materials from wood and hemp production processing remains, which are seen in Fig 1 to 4.

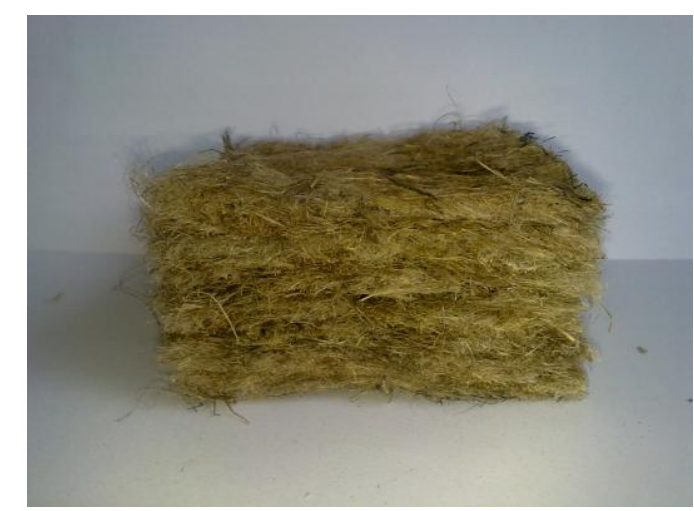

Fig.1. A1 Hemp fiber composite material

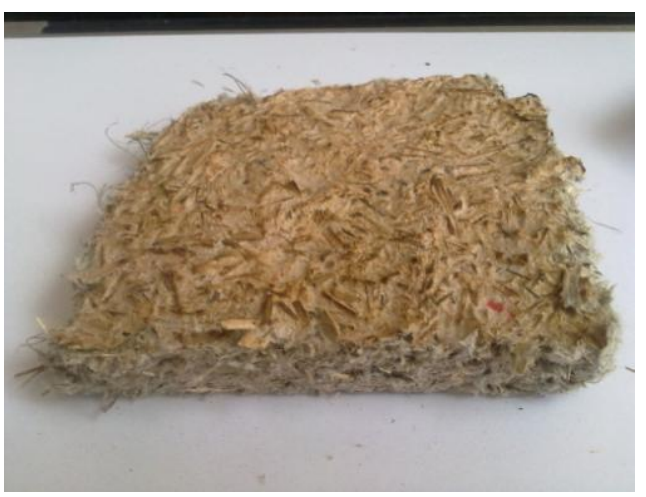

Fig.3. C1 Hemp shive and cellulose composite material

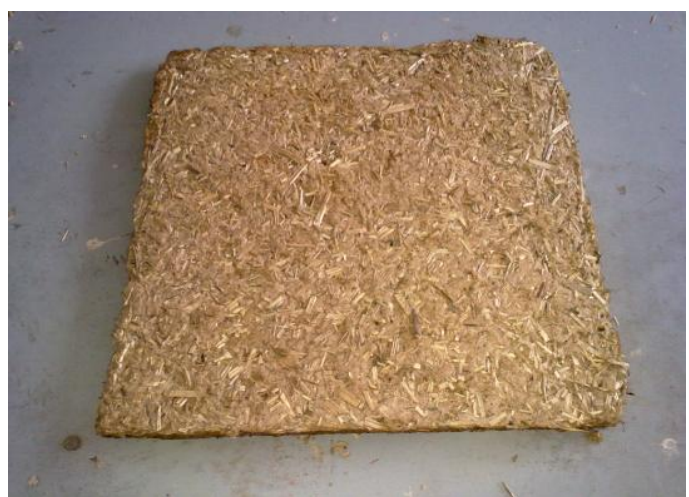

Fig.2. B1 Hemp shive and wood fiber composite material

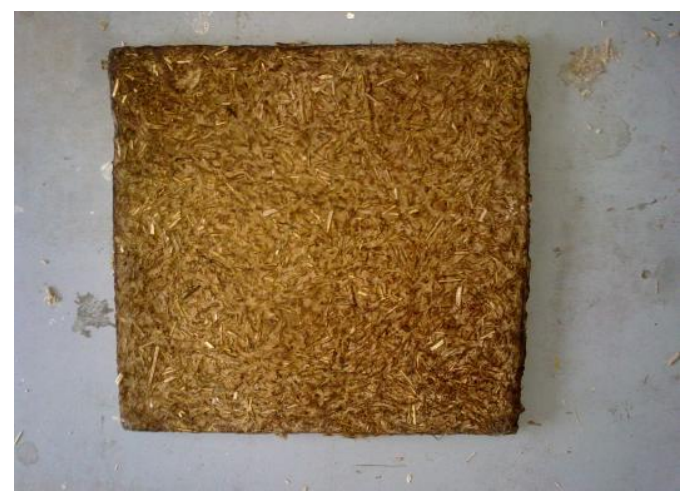

Fig.4. D1 Hemp shive and wood fiber composite material

Interrelation proportions of the produced insulation board ingredient research samples are seen in Table 1.

Viewing the obtained results about the insulating composite materials, it can be concluded, that it is possible to produce heat insulation materials of a high quality from the existing raw materials. It is possible to use in their composition only ecological binders and raw materials, and make the production process maximally simple. The obtained results are viewed in pictures 5 to 8 below. 
Interrelation between the Insulation Board Ingredients

Table 1.

\begin{tabular}{|c|c|c|c|c|c|c|c|}
\hline No. & $\begin{array}{c}\text { Wood } \\
\text { Fiber } \\
\text { Content, \% }\end{array}$ & $\begin{array}{c}\text { Hemp } \\
\text { Fiber } \\
\text { Linters, } \\
\%\end{array}$ & $\begin{array}{c}\text { Hemp } \\
\text { Wood } \\
\text { (Shive) } \\
\%,\end{array}$ & $\begin{array}{c}\text { Cellulose } \\
\text { (newspapers) } \\
\%\end{array}$ & $\begin{array}{c}\text { Used } \\
\text { Binder, \% }\end{array}$ & $\begin{array}{c}\text { Used Agent } \\
\text { against } \\
\text { Burning, \% }\end{array}$ & $\begin{array}{c}\text { Samples } \\
\text { Used in } \\
\text { the } \\
\text { Further } \\
\text { Research }\end{array}$ \\
\hline 1. & & $92-94$ & - & - & $\begin{array}{c}\text { Na silicate } \\
\text { solution,5 }\end{array}$ & Soda, 2-3 & A1 \\
\hline 2. & $30-33$ & - & $50-56$ & - & $\begin{array}{c}\text { Na silicate } \\
\text { solution,8 }\end{array}$ & Soda, 2-3 & B1 \\
\hline 3. & - & - & $50-56$ & $40-43$ & $\begin{array}{c}4 \text { Na } \\
\text { silicate } \\
\text { solution }\end{array}$ & Soda, 2-3 & C1 \\
\hline 4. & $30-33$ & - & $50-56$ & - & Starch,8 & Soda, 2-3 & D1 \\
\hline
\end{tabular}

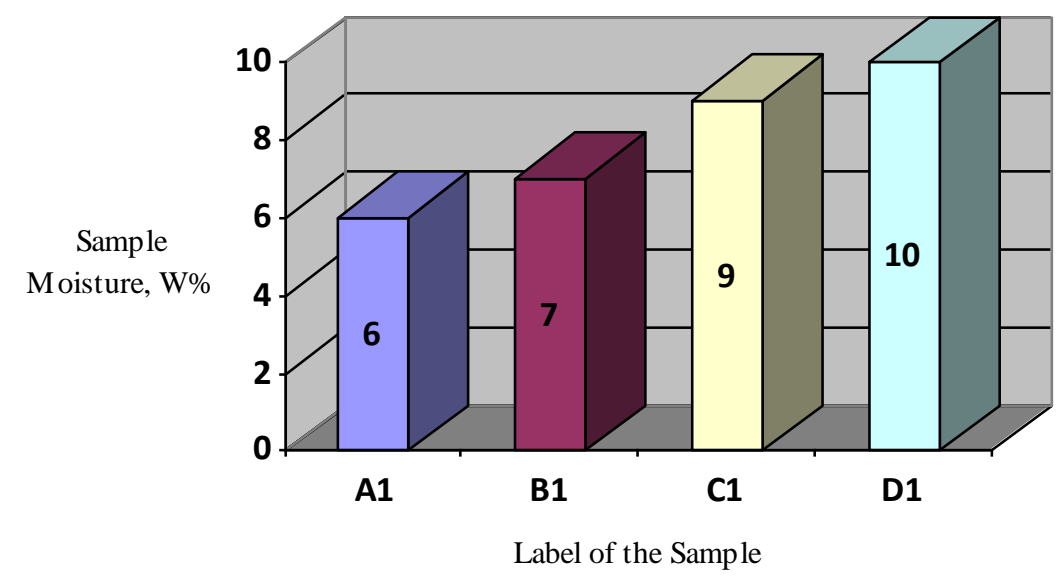

Fig.5. Average moisture of the produced samples after the drying, W\%

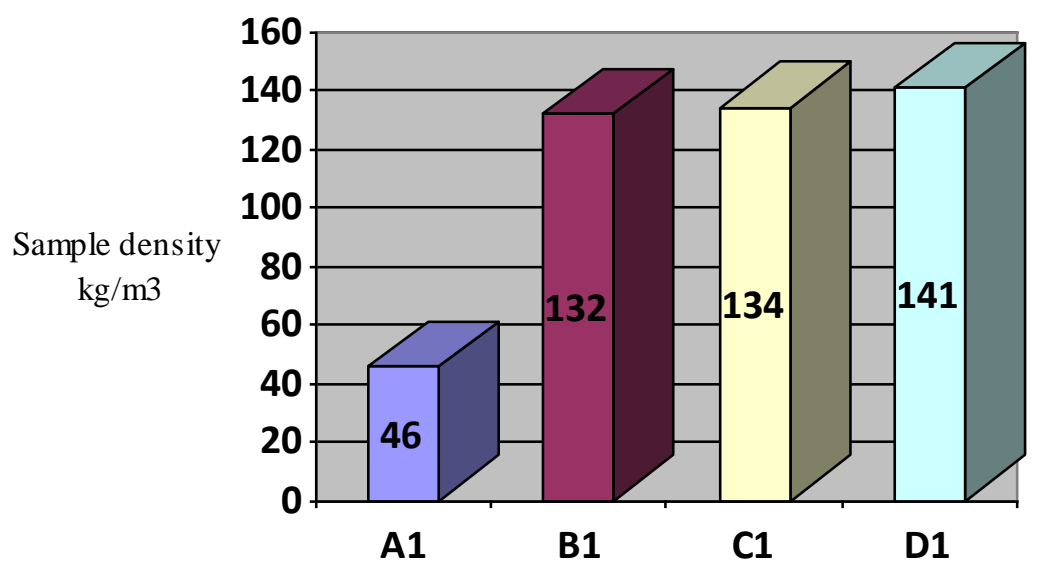

Label of the sample

Fig.6. Average density of the tested samples $\mathrm{kg} / \mathrm{m}^{3}$ 
Hemp, hemp and wood thermal insulation materials in the world are still new products that are in the developing phase, so it is necessary to study the creation of new materials and improvement of the existing ones. All the necessary Latvian and European Union (EU) standards and building codes should be taken into consideration as well.

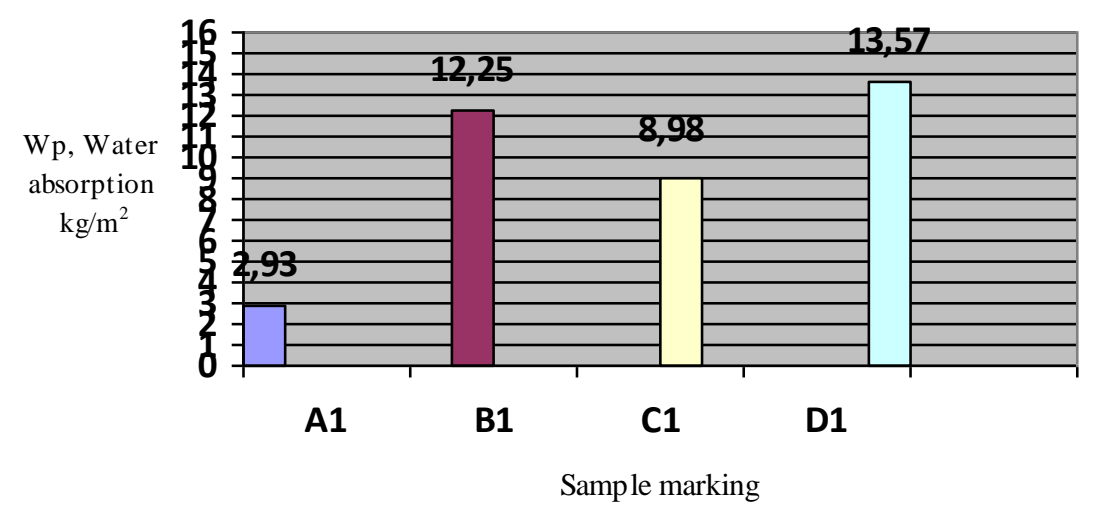

Fig.8. Water absorption capacity of the material samples

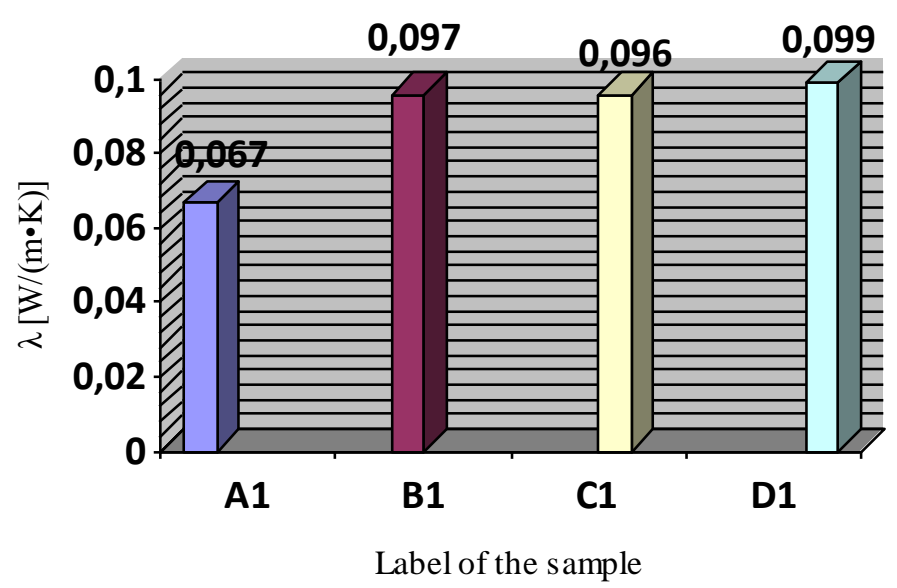

Fig.9. Thermal conductivity of the heat insulation materials

\section{Conclusions}

1. In the laboratory were carried out first studies and produced 80 samples. The results confirm that it is possible to produce the insulation plates from the production remains

2. During the testing of properties, the following results were obtained:

2.1. water content [W\%]: A1- 2.8-8.1\%, average 6\%; B1- 9.4-11.6\%, average 7\%; C1 $2.0-10.8 \%$, average $9 \%$; D1- 6.7-11.4\%, average $10 \%$.

2.2. density, $\left[\mathrm{kg} / \mathrm{m}^{3}\right]: \mathrm{A} 1-46 \mathrm{~kg} / \mathrm{m}^{3} ; \mathrm{B} 1-132 \mathrm{~kg} / \mathrm{m}^{3} ; \mathrm{C} 1-134 \mathrm{~kg} / \mathrm{m}^{3} ; \mathrm{D} 1-141 \mathrm{~kg} / \mathrm{m}^{3}$.

2.3. determination of the water absorption temporarily or partially keeping in water: A1$2.93 \mathrm{~kg} / \mathrm{m}^{2} ; \mathrm{B} 1-12.25$ [kg/m²]; C1- $8.98 \mathrm{~kg} / \mathrm{m}^{2} ; \mathrm{D} 1-13.57 \mathrm{~kg} / \mathrm{m}^{2}$. 
2.4. determination of the thermal conductivity coefficient $\lambda[\mathrm{W} /(\mathrm{m} \bullet \mathrm{K})]$ : $\mathrm{A} 1-0.067 ; \mathrm{B} 1-$ 0.097; C1- 0.096; D1- 0.099 .

Results are in line with EU requirements and construction standards.

3. Hemp and wood blend is a new insulation material, for which it is advisable in the future:

3.1. to determine properties of the optimal compositions,

3.2. to solve technological issues.

\section{Discussion}

For the analogue A1, produced worldwide, the thermal conductivity coefficient is $\lambda=0.045$ $\mathrm{W} /(\mathrm{m} \bullet \mathrm{K})$, but the data obtained in this research show that $\lambda=0.067 \mathrm{~W} /(\mathrm{m} \bullet \mathrm{K})$. That could be explained by the specificity of the used method. For the soft insulation plates the hot box method has to be used, instead of the hot plate method that was used in this research. As a result, the material was squeezed and lost its heat insulating capacity, thus increasing thermal conductivity coefficient $\lambda$.

\section{Reference}

1. Enerǵētisko augu audzēšana izmantošana, Valsts SIA „Vides produkti”, 2007

2. LVS EN 1602:1996+AC:1997. Siltumizolācijas materiāli lietošanai. Šķietamā blīvuma noteikšana, 2002. Page 9

3. LVS EN 1609:1996+AC:1997, Siltumizolācijas materiāli lietošanai būvniecībā. Ūdens absorbcijas noteikšana īslaicīgi un dal̦ēji izturot ūden̄̄, 2002. Page 10

4. LVS ISO 8302:1991, Siltuma izolācija. Siltuma pretestība un ar to saistīto īpašību noteikšana stacionārā režīmā. Norobežotās karstās plāksnes ierīce, 2001. Page 48 